\title{
The Foundation and Development of British Guiana
}

\section{Author(s): J. A. J. de Villiers}

Source: The Geographical Journal, Vol. 38, No. 1 (Jul., 1911), pp. 8-23

Published by: geographicalj

Stable URL: http://www.jstor.org/stable/1779020

Accessed: 19-06-2016 13:24 UTC

\section{Your use of the JSTOR archive indicates your acceptance of the Terms \& Conditions of Use, available at}

http://about.jstor.org/terms

JSTOR is a not-for-profit service that helps scholars, researchers, and students discover, use, and build upon a wide range of content in a trusted digital archive. We use information technology and tools to increase productivity and facilitate new forms of scholarship. For more information about JSTOR, please contact support@jstor.org.

The Royal Geographical Society (with the Institute of British Geographers), Wiley are collaborating with JSTOR to digitize, preserve and extend access to The Geographical Journal 


\section{THE FOUNDATION AND DEVELOPMENT OF BRITISH GUIANA.*}

\section{By J. A. J. de VILIIERS, Superintendent of the Map Room, British Museum, Hon. Secretary of the Hakluyt Society.}

$\mathrm{Mr}$ task is to give in one hour a sketch, based upon voluminous documents still inaccessible to the general public, of the foundation, development, and settlement of that portion of British Guiana which owes its rise to Laurens Storm van 's Gravesande-I mean, of course, the colonies of Essequibo and Demerara; incidentally, a brief biography of that remarkable but utterly forgotten man; finally, a résumé of the work performed by Robert Schomburgk for this Society and for Englandwork which followed the lines laid down by Storm van 's Gravesande, and which was taken up and completed during the last thirty years by Everard im Thurn and others.

This theme is developed in the book very recently issued in two volumes of the Hakluyt Society, wherein I had the pleasure of collaborating with Mr. Charles Alexander Harris, Chief Clerk of the Colonial Office, without whose valuable co-operation and comprehensive grasp of the subject that work could never have been satisfactorily written. When I remind my hearers that Lord Alverstone's speech on the boundaries of this colony before an Arbitration Tribunal in 1899 occupied thirteen full days, they will understand how difficult has been the task of compression.

British Guiana, our sole possession on the Spanish main, is divided into the three great counties of Essequibo, Demerara, and Berbice, all colonies founded by the Dutch. The earliest accounts of the country, more or less veracious, were written by Raleigh, Keymis, and Masham in 1596, by Cabeliau in 1599, by Leigh in 1604, and by Harcourt in 1613. The first Dutch historian who dealt with Guiana was de Laet in 1625, drawing for his facts upon the pioneers just mentioned and largely upon Spanish sources. He was followed nearly a century and a half later by Hartsinck in 1770 ; then Dalton in 1854, Netscher in 1888, and finally Rodway in 1891 dealt with the portion which is now British.

Even in Netscher's work, reliable and comprehensive as it is, gaps occur which are admitted and deplored by the historian himself. But these gaps have now been to a large extent filled up, for the origin and development of British Guiana has recently been the object of much deep research, necessitated by the perennial boundary controversies of the settlements on that coast. After extending over quite a century and a half, the diplomatic struggle was ended only within the last decade by arbitration between England on the one side and Venezuela and Brazil on the other.

The name Essequibo, which appears in several forms in the earliest writings-the most correct being probably Esscapi-is first connected

* Royal Geographical Society, May 8, 1911. Map, p. 112. 
with Dutch enterprise in Cabeliau's 'Account of the Voyage to America' performed in 1597 and 1598. Cabeliau, who was supercargo of this voyage, mentions "Essekebe" as one of the rivers lying between the Corentin and the Orinoco which were passed without investigation; but his report produced a petition to the States-General for permission to colonize Guiana, and it seems certain that private enterprise even ran ahead of the official policy which was embodied in the charter granted to the Dutch West India Company in 1621.

The precise date of the first settlement of Essequibo is possibly one of those problems which will never be solved. The only definite statement extant is that contained in a manuscript penned by Major John Scott, geographer to Charles II., in or about 1669, which attributes the foundation to one Gromweagle (really Groenewegen), who, in or soon after 1616, is stated to have erected a fort " on a small island, 30 leagues up the river Isseekeeb." This is clearly Fort Kijkoveral, which for nearly a century was the centre of the Dutch colony. Scott's veracity in this and in other matters has not been unimpeached, and I have but recently stumbled across a highly imaginative pedigree of his written by himself; yet this statement concerning the formation of the Essequibo settlement receives a measure of confirmation from a French manuscript of 1624, which indicates that there was at that time a settlement in Essequibo of some years' standing. This interesting journal of the " Voyage faict par les Pères de Familles" contains a precise account of the entrance to the river "Eziquebe" and a sketch-map of the anchorage close to the site of Fort Kijkoveral which leaves no doubt as to accurate knowledge of that position; it also contains observations which imply a previous acquaintance with the district and an already existing trade.

Not later than 1625, at any rate, the settlement of Essequibo had begun to be exploited by the Dutch West India Company, and we can thenceforward follow its internal development by authentic and welldefined references to its trade and its officers.

One word as to the value and scope of this trade. The trade in the interior was of two kinds-trade by officials of the Company; trade by private individuals with legally protected rights. This dual and competitive system of trade carried on with the natives naturally led to exploration and extended influence. In Guiana, as often elsewhere, the private traders went in advance of the flag; this was borne by the slower-moving company, often, as the documents show, by the natives themselves. There is evidence, beyond all doubt, that within a few years after they had settled at Fort Kijkoveral, the Dutch had penetrated, by way of the Essequibo and connecting waterways, to the region bordering on the Amazon, and that a great portion of the district which lay between the Rupununi and the Amazon was covered by their systematic trade. We see, in fact, not only from Dutch, but also from reliable Spanish and Portuguese sources, Dutch trade flowing as a strong 
under-current in the history and development of the colony from 1625 onwards. It were impossible for me to give its details to-night. Of the highest interest and deepest import with regard to Dutch and British claims in the hinterland of Guiana, these details (that often take even a romantic turn) deserve treatment in a separate paper, that would have to deal also with the subjection by the Dutch, through the influence of such trade, of various powerful Carib tribes.

But I must now go on with the main theme before us. In 1704 was born Laurens Storm van 's Gravesande, the man under whose long administration the colony, as we know it, was organized, and the beginning of the eighteenth century marks the furthest extension of the sphere of Dutch influence which had its base in Essequibo. No subsequent efforts of the Dutch, no recent explorations of the British, have added to the area which was in a manner controlled by the then Commander, Samuel Beekman. Storm's part was to realize, to consolidate, and to give definition to the idea of territorial ownership. It was reserved to the British in the nineteenth century to give greater precision to this dominion, and finally to determine the boundaries of the colony. But the vague limits which may be assigned to the Essequibo settlement in 1700 were only in definition inferior to the boundary of the present day; in some directions they went far beyond it.

At that date the colony of Essequibo was centred round Fort Kijkoveral, which stood on an island some miles above the point where the Essequibo is joined by the united Massaruni and Cuyuni; on the main banks of the rivers, at the junctions, were some plantations of the Company's, and some others belonging to private individuals; cultivation was rather slowly spreading down the lower banks of the Essequibo towards the islands which stud its mouth. To the eastward there was practically no settlement nearer than Berbice, which was formed in 1628, and the Demerara river was unopened. Westward the sphere of the Dutch extended along the coast to the mouth of the Orinoco, and in the interior also to the neighbourhood of that river; indeed, it may be said to have permeated the whole country between the Essequibo and the Orinoco. Southward up the main river of Essequibo there was at that time no station, but the Company's traders were quite accustomed to journey up as far as the mouth of the Rupununi, and also to proceed across country to a higher point on this river, along which they made their way to the savannahs which lie between Guiana and the Amazon, and probably, as I have already indicated, even further to the south.

Among the records that came into the possession of Great Britain when Essequibo and Demerara were transferred to her in 1814, were the reports sent home by the higher officials of the Dutch West India Company; and of chiefest interest in those reports is the series penned by Storm van 's Gravesande, a governor so utterly forgotten even in his own 
country in the nineteenth century that General Netscher, in his 'History of the Colonies of Essequibo, Demerara, and Berbice,' speaks of him as one of those meritorious Netherlanders "whose names are but little or not at all known, and who nevertheless deserve to be dragged from oblivion."

The whole of Storm's despatches, covering a period of thirty-four years-from 1738 to 1772 -would fill twenty-one volumes of three hundred octavo pages each. In its recent issue of a comparatively small selection from those letters, the Hakluyt Society had no intention to have the history of the colony written or re-written. The excellent and exhaustive work by Netscher just mentioned cannot easily be surpassed. But Storm's letters were unknown to Netscher, and Storm's life covers a very important if comparatively brief period in the colony's history, and even though it cannot be claimed that there was, de jure, any extension of the boundaries of the vast country entrusted to his jurisdiction, yet under Storm Essequibo reached the apex of its prosperity whilst subject to Dutch rule, under him Demerara was actually commenced. By his untiring energy the desert places were peopled, by his tactical ingenuity the native tribes were subjected, by his patriotic zeal his envious and bellicose neighbours were kept off. If not de jure, there was certainly extension de facto.

Born at 's Hertogenbosch on October 12, 1704, Laurens Storm van 's Gravesande entered the army in his seventeenth year, a somewhat hottempered youth, perhaps, for in his despatches he frequently mentions his habitual outspokenness, and late in life speaks of a quarrel he had in 1730 with his stepmother's father, the Burgomaster of Utrecht, which cost him his promotion. In spite of this it was the opinion of the Prince of Orange that he would have risen to the rank of general had he not elected to serve the West India Company in their colony of Essequibq as secretary and bookkeeper, for which office he took the oath in Middelburg in October, 1737.

Prizing and pocketing his colonel's hearty congratulations upon his advancement, the young soldier sets out for his new home-for, although he doffed the soldier's coat, Storm was before all and throughout all a soldier. The very first subject he deals with in his first letter home is neither sugar nor shipping-the two that interested the directors most, and were to give him so much trouble later-but the condition of the militia. Without an efficient force it was impossible even to keep the slaves in awe, let alone to repel Spanish encroachments, and year after year we find Storm urging upon the directors with wearisome reiteration the necessity of sending out reinforcements of honest, well-trained men. In addition to what was within the ordinary sphere of his work, Storm organized trading and mining expeditions that were to have far-reaching consequences for the colony, and had already in mind (for he had personally take: $\downarrow$ the soundings of the river) a new settlement in 
Demerara. So much disinterested industry could not long remain unrewarded.

Commander Gelskerke died in July, 1742, and the councillors, appreciating the extraordinary zeal and activity displayed-by the secretary, provisionally appointed him commander whilst awaiting orders from home; the appointment was made a definite one in Zeeland on April 13, 1743.

From that time onwards Storm's despatches teem with interest; but it is not my purpose to do more than summarize broadly Storm's main policy in those matters which affected the development of the colony.

It may be.said that the territorial consolidation of Essequibo constitutes the chief feature of Storm's governorship; and in three separate ways its story presents itself in his despatches:-first, in the definite steps taken to consolidate the possessions of the Dutch by a deliberate and thoughtful policy of development and exploration; secondly, in the policy pursued towards the various Indian tribes which Storm found in possession of the interior and coast; thirdly-and perhaps this is the most interesting of all-in the discussion as to the frontiers, and Storm's stout defence of the rights of the Netherlands against Spain.

The most interesting feature in the development of the colony under Storm was the rise of the province of Demerara. At the beginning of his administration Demerara was a mere trading area covered by the Company's traders, guarded by two trading posts, and only casually supervised from the fort. At his death it was the predominant partner in the colony.

It has not been hitherto demonstrated how much Demerara owed to Storm and his encouragement of the English settlers. With a less wise and independent man it might easily have been crushed in its infancy, or at least have been kept for many years longer under the jealous control of Essequibo. In this, as in many other matters, Storm laid the foundation of the present colony of British Guiana.

In the first muster-roll extant, dated 1691, two outlying stations are mentioned-one in Demerara, one in Pomeroon. In 1746 the Demerara was opened to general trade; its post was abolished as no longer necessary, since settlement along the river proceeded with remarkable rapidity, and within some five or six years was outstripping that of Essequibo.

In a despatch of December, 1748, Storm speaks of a crop of sugar in Demerara beyond all expectations, and expresses his hope that there would be a flourishing colony later on. He recommends the directors to send out special families as settlers, and indicates that the time has come when it is necessary to appoint somebody to administer the affairs of the new district. A couple of years later, in 1750, the last representation 
was duly accepted by the directors, who appointed Storm's own son to be the first commander of Demerara. To that part of our colony we will come back a little later.

Of Storm's masterly policy of exploration I will give you but one instance, though a very important one, for it finds a place in the historical geography of the world. Only a year after Storm's arrival in the colony, one Nicholas Horstman, a German surgeon in the employ of the West India Company, was sent up the Essequibo to find the passage to the Amazon river-I think I may venture to say, to rediscover that passage-to trade with the natives en route, and en passant to discover, if possible, the famous but mythical city of El Dorado, situated on the equally mythical Lake Parima-a lake that was portrayed as of enormous extent on all the maps of South America till then published.

Crossing the watershed between the Essequibo and the Amazon, Horstman found the true origin of the fable of the Golden Lake, just as Robert Schomburgk re-discovered it one hundred years later. It was only a small lake, Lake Amucu, which occasionally overflowed its shores and formed a great swamp. On reaching the Rio Negro, Horstman turned traitor and remained with the Portuguese. There he met La Condamine, and handed that traveller a copy of the map of the country he had traversed. That map, correct in its main features, was the first intimation to geographers of the true configuration of the land between the Essequibo and the Amazon. La Condamine handed it to d'Anville, a famous map-maker of the eighteenth century, and by him it was made the basis of a generally correct delineation of that part of the country in the first great map of South America, published in 1748. There, as you perceive, we find only the small Lake Amucu. So persistently, however, do we, even in the most exact of sciences, revert to ancient myths and beliefs, that d'Anville, twelve years later, reintroduces, in his map of 1760 , the dear old Lake Parima that Raleigh thought was there; and Hartsinck, though he should have known better, follows him as late as 1770. Humboldt often refers to Horstman's map in his 'Voyage aux régions équinoxiales.' It was lost for about a century, and was finally unearthed in the Bibliothèque Nationale in Paris by Mr. Charles Alexander Harris some ten years ago.

Horstman's expedition, abortive as it seemed at the time, had eventually that effect which Storm, undoubtedly its promoter, could have desired. It was the visible sign of an intention to take possession of the inland regions to the southward-the "uplands" of Guiana. It became in years long afterwards a leading proof of Dutch efforts in the interior around the sources of the Rupununi and Takutu-efforts that had already been made long years before by Dutch traders between the Essequibo and the Amazon. 
We now take Storm's native policy, which was a broad and enlightened one; so far as it was actuated by self-interest, it certainly recognized that self-interest was bound up in the general interest of the Indian tribes. It was an advanced policy for that age. In 1750 , when Storm was on leave in Europe, he made a special report to the directors of the West India Company, which contains a remarkably wise statement of his general Indian policy. While he treats the Indians as the natural friends and allies of the Dutch, he lays great stress on the folly of placing arms of precision in the hands of natives; his statements and arguments on this point are precisely those which have been familiar within the last halfcentury to British administrators in Africa. Nor did he overlook the danger that the competition of neighbouring colonies might frustrate his broader view, just as Great Britain has in West Africa had to face the reluctance of French or German merchants to adopt the policy which all in theory recommended.

Summed up broadly, Storm's general idea on this subject was embodied in a brief sentence of a despatch of 1762: "So long as we have the good fortune to stand well with the Indians (and I shall always try to remain so) and keep them under our protection, so long, I say, we need have no fear."

The result of the policy just described was shown at the time of a dangerous revolt of the negro slaves in Berbice. The actual force of this revolt was confined to a colony for which Storm was in no sense responsible. But danger to Berbice bred danger to Demerara and Essequibo ; so Storm disposed of the whole of his force to help Berbice in its extremity. He called upon the Indians from every part of the colony. He set Caribs and Arawaks in motion throughout Essequibo-from the Rupununi and the Cuyuni to the Corentin and the Abari ; and in large measure to this successful use of the Indians we may attribute the safety of the sister colony.

The results of Storm's Indian policy remained down to our own times. The Indians claimed from the British in the next century the privileges and alliance which they had enjoyed under the Dutch; and the position was readily accepted.

When all is said and done, it is the diplomatic side of Storm's administration which is the most interesting and perhaps the most important. Storm's investigation of the boundaries of the colony under his command, and his maintenance of the rights of the Dutch company against the aggressions of the Spaniards were at once the foundation- and the copingstone of his efforts to consolidate that colony as a geographical unit. It is impossible to exaggerate the importance which his despatches had in the recent boundary dispute between British Guiana and Venezuela. Just as his careful trade administration and his Indian policy fixed the geographical extension of Guiana, so his vigorous denunciation of Spanish 
claims and his insistence on the responsibility of the Dutch company to their furthest limits furnish the legal basis upon which the British found their title to their one South American colony. Again, I will give you but a single instance.

In September, 1758, Storm reports to the directors at home that the Cuyuni post had been raided by the Spaniards. Nearly all the Caribs living on the river had come downstream and reported that Spaniards from Orinoco, estimated at about one hundred, had made a successful raid upon the post, carried off the post-holder and his assistant, laid waste the post and all around it, and threatened to come down and serve the whole colony in the same way. Storm took the whole affair with rare good sense. With very little delay he addressed a despatch in French to the commandant in Orinoco, protesting against the action which had just been reported to him, and dealing in terms of dignified remonstrance with the violation of territory, which now bid fair to disturb the peaceful relations between Spain and the Netherlands. He got scant satisfaction. Haughtily and vaguely the Spaniards claimed that the river Cuyuni was in Spanish territory, and that the Dutch post-holder was carrying on a slave trade within the Spanish dominions; the restitution of the prisoners was declined. In the name of the States-General, his sovereigns, Storm persisted in his remonstrance, and for the second time demanded the liberation of the prisoners and suitable satisfaction for the violation and insult done to the territory he administered. He warned the Spaniard at the same time that the whole correspondence was being sent to Europe, and that he had every confidence that the Government in Madrid would, without hesitation, give complete satisfaction.

The resolutions of the Dutch West India Company read very lame by the side of Storm's vigorous protests. But it is probable that he had backed up his official despatch by one of his private communications to the advisers of the Prince of Orange, and in August, 1759, a formal remonstrance by the States-General was on its way to the Court of Spain. A second remonstrance in August, 1769, after another raid, may be counted as the crown of Storm's diplomatic efforts. It was received with courtesy and attention by the Spanish, and though it never had a final and direct answer, even after fifteen years of consideration, it practically stopped overt acts of aggression.

The document is interesting as embodying a formal claim to the colony as it then stood, namely, that the Dutch had "from time almost immemorial been in possession not only of the river Essequibo and of several rivers and creeks flowing into the sea along the coast, but also of all branches and streams which fall into the said river Essequibo, and more particularly of the most northerly arm of the said river called the Cuyuni." Much the same assertion was contained in the earlier remonstrance of 1759 , and may be looked upon as the definite claim in the face of the world to the boundaries of the territory to which Storm had devoted his life. 
We must now go back a little to more internal affairs of the colony.

In March, 1749, Storm deemed it very desirable to give his masters a full verbal report of the condition of affairs, and therefore applied for leave to visit Europe. The leave was granted, but the visit was illalvised. Storm's absence of two years from a colony seething with godlessness and disloyalty proved too great a strain for the maintenance of what slender authority he possessed; the commander, well received at home by the ruler, Prince William IV., and other magnates, was raised to the dignity of Director-General, and his eldest son was given the commandership of the newly founded settlement of Demerara; the Company, however, seized the opportunity of insisting upon what is referred to as their "great reform," a system of false economy first mooted in 1744, and Storm returned to the colony to find his prestige greatly impaired. Spoors, the secretary, had (probably as a complimentary prolongation of his provisional administration during Storm's absence) been given official direction, conjunctim with the Director-General, over the Company's plantations; this annoyed Storm, for if it lessened his responsibility, it must also frequently have led to a conflict of opinion. The planters, moreover, regarded the head of the colony (more than ever since his visit home) as the mouthpiece of a Company which neglected their interests and sought only its own profit. Storm had henceforth a treble battle to fight-discontent within, invasion ever imminent (or what was nearly as bad, a fear of it), and neglect, born of dissatisfaction, on the part of the home authorities.

Already in 1744 Storm had written home, "The non-supply of slaves is another matter that greatly retards the rapid growth of the colony. . . . If no remedy be found it will always remain an immovable obstacle in the way of all progress."

But, as he himself says late in life, "Mine was the fate of Cassandra." And as with slaves, so with supplies. Appeal follows upon appeal, but later references prove that all were equally without results so far as regards the regular upkeep of shipments.

Consolation for and distraction from his troubles Storm found in naught so much as in the pleasure he derived from the rise of Demerara. And that pleasure came at a very opportune moment. Only a few months after his return in 1752 , he writes most optimistically of the progress being made by the young colony commenced in 1746 , mentioning both the activity of one Gedney Clarke, of Barbados, and the coming of other planters from other isles. The next year he exults in the number of allotments made for plantations, and relates that the inhabitants, " of whom by far the greater number consisted of English or of those understanding the English language," had begged for permission to hold divine service in their mother tongue, which " most laudable request" he " immediately granted." 
In the very next letter to that in which he announced Clarke's enterprise, Storm, introducing him, as it were, to his directors, speaks of him as "a man of judgment and of large means, having the welfare of this colony really at heart." And Clarke, by his subsequent conduct, fully justified Storm's opinion of him on both these points, for it was by his prompt aid that the colony was, a decade later, saved from ruin.

Whether Storm's friendly relations with the Clarkes-father and sonwere dictated, in their inception, by policy, or were simply the outcome of reciprocated esteem, it is difficult to determine, but the friendship was of far-reaching consequences for the colony. It warded off, in 1764, a calamity similar to that which had just befallen Berbice, and at a moment when the means at Storm's disposal were too slender to cope with it. When the alarm came, Storm was sufficiently diplomatic not to apply in the first instance for direct aid from the English, simply informing Clarke, who had large estates in Demerara, of the danger that colony was in. When the danger became more imminent, and he had resolved, "after long deliberation and reflection," to ask the Governor of Barbados, in the name of the States-General, for the aid of two hundred men, "should the state of affairs after due examination require it," Clarke's activity rendered it unnecessary for Storm to carry out his resolve. Nevertheless, in spite of his subsequent declaration (in reply to the Company's inquiry) that " direct assistance I never asked for, although I was on the point of doing so once," Storm handsomely admits, and more than once, that the succour sent by the English "was, after God, the salvation of Demerara."

The last and shortest of the three periods into which Storm's colonial career was carved by the incidence of events was not, as befitted the evening of a life spent in duty, one of peace and calm, but in direct antithesis to what the man deserved and desired-a time of ceaseless troubles for which he was not responsible and over which he had but little control.

In June, 1764, he writes, "Mr. Spoors [the secretary] has almost lost his sight. . . This grievous occurrence . . . brings such a whirl of matters upon me that I see no getting through them."

And in August we have the following pathetic announcement: "On July 20 it pleased the Almighty to take my son, Gerard Johan, from this temporal to His Eternal Kingdom, at the age of twenty-four; of my six sons I have therefore none left but the youngest, who has gone to Europe in the country's warship Zephyr. Painful occurrences in my old age, and following, too, so closely upon each other; but we have to submit to the will of the Most High-who can ward off His hand or say to Him, "What doest Thou?",

Yet so untiring was the energy of the man that by the same vessel which carried the despatch announcing his son's death he sent home "a

No. I.-JuLY, 1911.] 
short treatise concerning plantership"- -translated "during odd moments of leisure"-and a long and important report upon the Company's trading posts. All this time Storm's duties were ever increasing, and no thought was there on his part of shirking them, though his faculties were failing him fast. It is, then, the more cruel irony that the men so ironically misnamed directors, who for a long series of years had systematically starved the colony in rations, slaves, and means of defence, who regarded it as politic to keep in office, much against his will, their faithful but decrepit servant, should, but a few months before releasing him from a service of thirty-five years, accuse him of "bad and unjustifiable management," suspect him of a lack of " honesty, attention, and economy" !

Themselves importing no slaves, they rail against the illicit but unavoidable importation by the English; sending insufficient rations, they complain that their slaves are kept short of them; supplying not even the most rudimentary requisites for the plantations, they express dissatisfaction with the yields. Children playing a game would act more logically than did they.

Early in August, 1772, Storm foreshadows trouble, hints at its cause, and explains his humane and statesmanlike efforts to stem it. But the storm burst, and once more the colony was, by a serious slave rising, brought to "the brink of total ruin."

As throughout, so was Storm a soldier to the end. His despatches of August and September, 1772 (the last he indited), are all that such documents at such a time should be-exactly explicative of events and of measures taken, commendatory of those who had distinguished themselves in valour, and advisory respecting future means of defence. His successor, George Hendrik Trotz, arrived at Fort Zeelandia on November 27,1772 , and Storm's career was over, salvis honoribus, as he had so ardently wished. He immediately retired to his plantation in Demerara, where he died August 14, 1775, in his seventy-first year. Storm passed quietly into oblivion whilst strangers enjoyed the fruits, and for a long time the fame of his lifelong work; hence the words he had himself so often applied to his efforts on behalf of the colony form his most fitting epitaph-

\section{Hos ego versiculos feci, tulit alter honores.}

Storm's successor carried on the main traditions of his predecessor's policy, particularly as regards the natives; from this time a policy of organizing Indians under Dutch control became a permanent one. Staves of office, first suggested by the Court of Policy in 1774 and apparently first awarded in 1778, became the ordinary symbol of a chieftainship in alliance with the Dutch, and this definite Indian connection grew to be the mainstay of Dutch administration in the interior. The special relation subsisting between the Indian tribes and the Dutch was almost naturally transferred to the British when, thirty years later, 
they finally took over the colony; and it will be found to have formed one of the chief safeguards of the territorial claims which the British have recently made good before the world.

Meanwhile, as Storm himself had foreseen, Demerara was developing far faster than the older settlement; in spite of great increase in the grants of land on the Pomeroon, the centre of gravity was gradually shifting to Demerara. The success of the sugar plantations in the hands of certain pushing English settlers added a special impulse to this tendency.

In 1781 war broke out between the English and the Dutch, and one of the first British successes in the West Indies was the capture of Demerara. This was followed by the fall of Essequibo and Berbice. Between that time and the end of the eighteenth century the three colonies repeatedly changed owners, but in September, 1803, they once more fell to the British, whose hands they never left again, being finally ceded under the Treaty of 1814. In 1831 Berbice was united with Demerara and Essequibo; henceforth they were but three counties or provinces of British Guiana.

We now pass to the most interesting and important series of explorations ever undertaken in the country, and it is noteworthy that they followed very quickly upon the final unification of the old Dutch colonies under one government. Robert Schomburgk was first sent out by the Royal Geographical Society as a result of a resolution taken in 1834 to explore the interior of the colony, this project having in some measure been suggested by Humboldt's journeys, and having, as the Journal of the Society records, received the fullest sanction and patronage of His Majesty's ministers. Schomburgk's reports and journals throughout the whole of his explorations form one of the most complete and interesting narratives with which the annals of geography have ever been enriched.

Schomburgk was a man with remarkable capacity for observation. He combined great natural genius as a surveyor with the eye of a botanist and the training of a naturalist. His references to the Indian tribes are full of a sympathetic intelligence which renders him, even at this date, one of the best chroniclers of Indian manners and customs.

Leaving Georgetown in September, 1835, he proceeded up the Essequibo, beginning the serious ascent of that river in October. He followed the line of the old Dutch traders, turned to the west up the Rupununi, and halted in November at Annai. From that centre he explored the whole of the Rupununi and the savannahs which surround it, and took the first step towards exploring the Mahu. He also made his way up the Essequibo proper to the great fall which he named after King William IV., and investigated the paths connecting the Essequibo with the upper reaches of the Demerara river. In the following year (1836) his work was the ascent of the Corentin and the Berbice, on the other side of the colony. In 1837-8 Schomburgk carried out the design upon which he was mainly bent, and discovered the sources of the 
Essequibo, where he hoisted the British ensign; he also reached the Acarai mountains, on the watershed between the Essequibo and the Amazon. He then proceeded with a journey which took him outside the boundary of the colony, and had results far beyond those of simple exploration. The object of his expedition, as he puts it himself, was, after examination of the Essequibo sources, to connect his journeys from the east with those of Humboldt at Esmeralda, on the upper Orinoco.

The representations which, on his return to England in 1839, Schomburgk made as to the needs of the Indians on the savannahs near the Rupununi, and to their danger from Brazilian raiders, attracted notice in Parliament. The British Government decided that steps must be taken to stop further interference with the natives and violation of territory which was believed to belong to Great Britain. It was therefore decided to send Schomburgk to make a complete exploration of the boundaries of British Guiana, and to mark them provisionally, subject to due notice to neighbouring powers. The announcement of Schomburgk's appointment to the other governments interested brought up at once the whole question of boundary, not only on the side of Brazil, but also on that of Venezuela.

Between April, 1841, and October, 1843, Schomburgk, now accompanied by his brother Richard, covered practically the whole boundary of British Guiana as it stands at the present day. Some temporary excitement in Venezuela was caused by this survey, but the consequent questions with the Venezuelan and Brazilian governments were soon quiescent. Negotiations came to a premature end without any result, and the reports of Schomburgk's surveys with the fine maps he produced lay buried for nearly half a century.

The colonists assumed that Schomburgk had pretty well settled boundary questions, and not being troubled with further claims from Venezuela or Brazil, they set themselves to the development of the cultivated districts, where coolie immigration was coming to the aid of the planters and was starting the estates upon a new era of prosperity.

The Indians had little cause for anxiety as to their security, especially as it was notorious to them that Schomburgk, who had thoroughly won their confidence, had been marking a boundary, and that he claimed the land within that boundary as British territory. It is well known that the Indians moved inside the Schomburgk line, and so did their best to establish a well-understood frontier within which the jurisdiction of the British Government was admitted to run.

It was therefore not until the last twenty years of the nineteenth century that the boundaries of British Guiana were finally and legally settled. The journeys of the Dutch traders, the efforts of the postholders under Storm, the explorations and surveys of Schomburgk, work such as that of Sawkins and Barrington Brown (which I have had to pass over through lack of time)-in fact, all attempts to fix 
the geography of the colony, found their ultimate result in the decision of two arbitral tribunals. Similarly, the work done by Storm in defence of the rights of the Dutch, the Indian policy initiated by the Dutch and carried out through so many years by the British, and the determination of the British to make good the rights which they inherited from the Dutch -all found their justification in the decision of those two tribunals.

What may be described as the last chapter in the history begins in the late seventies with certain travels and explorations by British officials of the colony, chiefly by two men whose names became inseparably connected with the question of the boundary.

In 1878, Everard im Thurn, then a young man not long from Oxford, obtained leave to spend a holiday in the savannah district in the south of the colony. There he stayed some months amongst the Macusis and the Wapisanas, becoming better acquainted with those Indians than any other European had ever been before him. The book which he published on the subject is a classic, and therein Mr. im Thurn remarks that the line laid down by the Boundary Commission under Schomburgk was accepted in that district by both the British and the Brazilians. In the same year, Michael McTurk, an officer in the service of the colony, was appointed special magistrate and superintendent of Crown Lands and Forests of Essequibo. Possessing the full confidence of the natives, a daring leader capable of taking any risk and of undergoing any privation, McTurk was a man marked for the performance of the exceptional duties assigned to him. He had become, in fact, a sort of official explorer of the colony, and it might be safely stated that in scarcely a single year since 1878 has he failed to add something to the knowledge of Esserguibo possessed by the British Government.

Expeditions were made by Mr. McTurk with Mr. Boddam Whetham in 1878, and by Mr. Henry Whitely in 1883, in the forest zones round the Pacaraima mountains with a view to the ascent of Roraima: each had its interest, but the successful undertaking was reserved to $\mathrm{Mr}$. im Thurn and Mr. Harry Perkins in 1884. Up to that year Roraima had been considered inaccessible; im Thurn performed the feat of asc nding the great sandstone cliff and exploring the whole of the flat top. Roraima stands at the junction of three states, and technically it belongs to all three-Britain, Venezuela, and Brazil ; but in fact it is essentially a British mountain, discovered by the British, ascended by the British, and reported on only by British authorities. This expedition of im Thurn's may be looked upon as the last effort of exploration for its own sake in British Guiana. Later incidents that took place brought the boundary question definitely to the fore, and made it impossible to view any subsequent exploration apart from the question of claim to a particular boundary. One of these incidents was the final declaration in 1886 by the British Government of the Schomburgk line as the definitive boundary 
of the colony; another was the decision to organize as the "NorthWestern district" of the colony the coast region between the Pomeroon and Demerara, where there were already a number of occasional, if irregular, settlements by British subjects. Such decided action by Great Britain led to the suspension of diplomatic relations with Venezuela in the early part of 1887 . In the course of that year rumours of gold discoveries along the boundary, combined with the publication of a Venezuelan concession over territory which Great Britain claimed, led the local Government to issue a proclamation which specifically reserved British rights over the most extended boundary which had ever been claimed by the Dutch, i.e. the whole basin of the Cuyuni river and its tributaries, including the area occupied by the Spaniards who had been such a thorn in Storm's side.

On December 18, 1895, President Cleveland issued the celebrated message in which he called upon Great Britain to submit the whole question of the boundary to arbitration. Arbitration was not yet then such a familiar word with us as it is to-day, and such a breach of ordinary diplomatic routine took the whole world by storm. For a few days two great kindred nations were on the verge of war; then wiser counsels prevailed, and early in 1896 the British Government gave way. Venezuela placed its case in the hands of American jurists, and each side prepared case, counter-case, and argument, in which the history of three centuries was laid under contribution. After more than two years of this preliminary argument on paper, a Tribunal met in Paris in 1899, and a judgment was given which in effect sustained the whole claim of Great Britain to the Schomburgk line. The only material divergence was at the mouth of the Barima. Here the Tribunal, apparently influenced by the arguments of American counsel on the ground of national safety, decided that the British boundary began at a point some distance eastward from Point Barima, and so gave to Venezuela the mouths of both the Amakuru and the Barima. Thus, by the Award of Paris of 1899, the northwestern boundary of the colony was finally settled, and the line accepted by the Tribunal was a line which would have fairly satisfied the claims made by the old Director-General Storm some 140 years before.

Negotiations for an arrangement with Brazil were actively prosecuted as soon as the award in the Venezuelan matter had cleared the ground of that question, and these resulted in a treaty of arbitration signed in November, 1901. By this treaty the two governments agreed to limit their claims by a definite zone, and to submit the question of boundary to the decision of the King of Italy. In the centre of that zone was Pirara on Lake Amucu, the site of the fabulous Lake Parima and El Dorado, and the path of the old Dutch traders first mapped by Horstman. This arbitration was conducted entirely by written case and argument; His Majesty gave his award in June, 1904, and that award may also be claimed as a considerable triumph for Schomburgk's line. The Mahu 
and Takutu were made the boundaries of Brazilian territory, and in this way Great Britain preserved both her rights to the savannah country beyond the Rupununi, which had been dominated for 300 years by the Dutch and British, and also her suzerainty over the Wapisana and Macusi Indians, who had for years relied on the protection of the abovenamed nations.

Thus by the end of 1906, by which date the actual work of delimitation, too, was completed, British Guiana for the first time had its boundaries definitely fixed, and though those boundaries almost certainly did not go so far as Dutch influence at one time went, still they included most of the territory for which Storm van 's Gravesande had always contended, and they justified in a marked degree the line drawn by Robert Schomburgk.

The President (before the paper): Mr. de Villiers, who has kindly consented to read a paper to-night on British Guiana, is very well qualified to deal with all questions connected with that colony, whether geographical or historical. As to geography, I may perhaps mention that he is now in charge of the Map Room of the British Museum; whilst both from the point of view of geography and history he has had exceptional opportunities of studying the affairs of British Guiana. During three years he was employed by the Foreign Office in connection with the Venezuelan arbitration, and at a later date he was for three or four years employed on similar duties with regard to the demarcation of the boundary between Brazil and British Guiana. In the course of these investigations he had to visit Lisbon and the Hague, and to study vast piles of Dutch and Portuguese records. The result of this investigation was, amongst other things, the publication. of two volumes published by the Hakluyt Society containing an account of the doings of an early Dutch administrator of the new British colony. The hero of this romance of real life, whose name was Storm van 's Gravesande, was in truth an able and remarkable man, well deserving of Mr. de Villiers' sympathetic appreciation.

Sir Clements Markham : I will make a few brief observations, and be as short as possible, because we have here present the highest authority on the cartography of Guiana, who will address you in a much more interesting way than I can. We have, I am sure, all enjoyed listening to Mr. de Villiers' interesting paper, and admired the way in which he has brought before us the great administrative ability of a distinguished Dutch statesman, who practically founded the colony of Guiana, who administered it with great skill, who established an admirable system of friendly relations with the Indian tribes, and who, above all, promoted exploration in that country. The name of Horstman, I must acknowledge, is new to me, and I was not aware that D'Anville had obtained the results of his explorations in that unknown region as far as the Rio Negro. I should be tempted to say a good deal more on that region, and to refer to the little we know of it, but there is not time. The inheritance which we received from Storm was a very noble one, and then this Royal Geographical Society stepped in. One of the first expeditions that it promoted was that for the exploration of Guiana by Sir Robert Schomburgk. I am old enough to have been acquainted with Schomburgk, perhaps the only one in this room who was acquainted with him-not, I must allow, when he was exploring Guiana, but years afterwards during his service in 


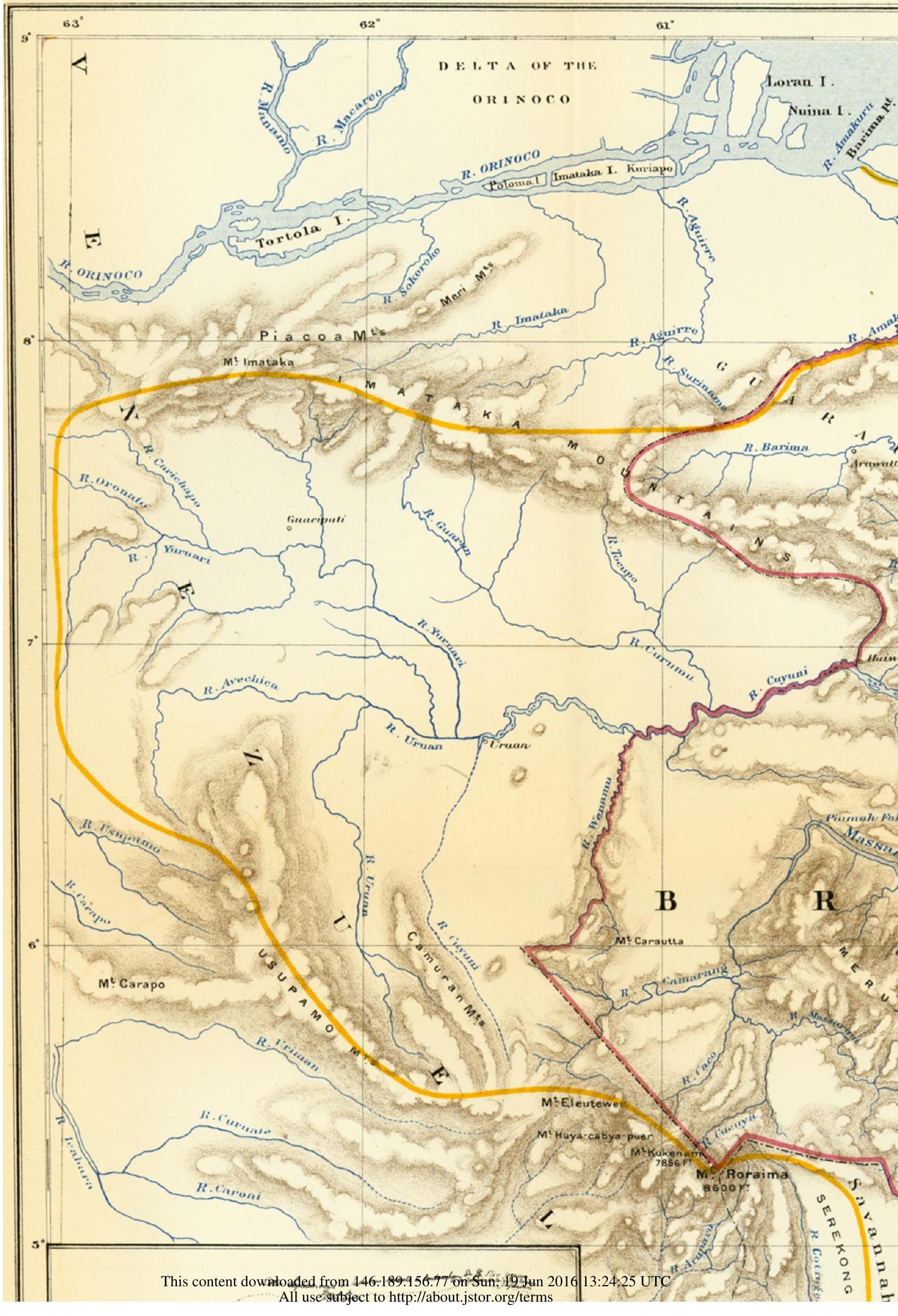


